\title{
IMPACTO DE LA CALIDAD DE AGUA PARA BEBIDA ANI- MAL EN RELACIÓN A PARÁMETROS PRODUCTIVOS, COMPOSICIONALES Y REPRODUCTIVOS
}

\author{
ReVelli, G. R. ${ }^{1} ; \quad$ Sbodio, O. A. ${ }^{2} ;$ Tercero, e. J. ${ }^{2}$ \& Uberti, M. ${ }^{1}$
}

\section{RESUMEN}

Muestras de agua subterránea de 36 establecimientos lecheros pertenecientes a la Cooperativa Tambera Nueva Alpina Ltda., fueron recolectadas entre Enero de 1997 y Diciembre de 2001.

Se realizaron análisis fisicoquímicos $(\mathrm{pH}$, Conductividad, Turbidez, Oxígeno Disuelto, Temperatura, Salinidad, Sulfato, Nitrato, Nitrito y Dureza Total) con el objetivo de categorizar las mismas en función a su calidad y aptitud para consumo animal.

Los datos se relacionaron estadísticamente con parámetros productivos (Promedio Litros Totales/ Vacas en Ordeño), composicionales (Grasa Butirosa, Proteína Verdadera, Lactosa, etc.) y reproductivos (Intervalo Parto Concepción).

De todos los parámetros de calidad de agua analizados, las correlaciones más significativas en función a los indicadores en estudio fueron para: Sulfato vs. Grasa Butirosa $(\mathrm{r}=-0,978 ; P<0,05)$, Dureza Total vs. Proteína Verdadera $(\mathrm{r}=-0,978 ; P<0,05)$, Dureza Total vs. Sólidos Totales $(\mathrm{r}=$ $-0,956 ; P<0,05)$ y Nitrato vs. $\mathrm{pH}(\mathrm{r}=-0,993 ; P<0,01)$.

Esta experiencia nos alerta sobre componentes presentes en el agua que merecen ser estudiados profundamente, ya que en niveles elevados ocasionan pérdidas significativas en nuestros sistemas de producción.

Palabras clave: calidad de agua, producción lechera, composición de leche, reproducción.

\section{SUMMARY}

Impact of water quality for animal drink in relation with productive, compositional and reproductive parameters.

Samples of underground water of 36 dairy farms belonging to the Cooperativa Tambera Nueva Alpina Ltda., were collected between January of 1997 and December of 2001.

Physicochemical analysis were carried out ( $\mathrm{pH}$, Conductivity, Turbidity, Dissolved Oxygen, Temperature, Salinity, Sulfate, Nitrate, Nitrite and Total Hardness) with the objective of categorizing the same ones in function to their quality and aptitude for animal consumption.

The data were related statistically with productive (Average Total Liters/Milking Cows), compositional (Butyrous Fat, True Protein, Lactose, etc.) and reproductive (Interval Leave Conception) parameters.

1.- Laboratorio Integral de Servicios Analíticos (L.I.S.A.). Cooperativa Tambera Nueva Alpina Ltda.

(2340) Ceres, provincia de Santa Fe, Argentina. e-mail: lisa@inthersil.com.ar

2.- Universidad Nacional del Litoral, Facultad de Ingeniería Química, Instituto de Tecnología de Alimentos (I.T.A.). Casilla de Correo 266, Santa Fe, Argentina.

Manuscrito recibido el 24 de abril de 2002 y aceptado para su publicación el 7 de junio de 2002. 
Among all parameters of water quality analized, the most significant correlation in function to the indicators in study were for: Sulfate vs. Butyrous Fat $(\mathrm{r}=-0,978 ; P<0,05)$, Total Hardness vs. True Protein $(\mathrm{r}=-0,978 ; P<0,05)$, Total Hardness vs. Total Solids $(\mathrm{r}=-0,956 ; P<0,05)$ and Nitrate vs. $\mathrm{pH}(\mathrm{r}=-0,993 ; P<0,01)$.

This experience alert us about components present in the water that deserve to be studied deeply, because high levels cause significant losses in our production systems.

Key words: water quality, dairy production, milk composition, reproduction 